This is a pre-print version of an article first published online in Social Policy and Administration on $31^{\text {st }}$ July 2014. Available online at http://onlinelibrary.wiley.com/doi/10.1111/spol.12095/full

\title{
Nationalist reframing of the Finnish and Swedish welfare state: the nexus of nationalism and social policy in far-right populist parties
}

\begin{abstract}
The rise of right wing populist parties in the Nordic countries is slowly redefining the Nordic social democratic discourse of the universal and egalitarian welfare state. The nexus of nationalism and social policy has been explored in regions and countries such as Quebec, Scotland, Belgium and the United Kingdom but the change of discourse in the Nordic countries has received less attention. Taking the case of Sweden and Finland, this paper argues that Nordic populism does not question the redistributive welfare state per se as many other European neoliberal far-right parties have done. Instead it reframes welfare state as being linked to a sovereign and exclusive Swedish and Finnish political community with distinct national boundaries. Although Sweden and Finland largely share a common welfare nation state discourse, the article also points to important differences in the way this discourse is able to frame the welfare nation state where access to and the design of social services are no longer universal and egalitarian but based around ethnicity. The article aims to demonstrate this through an analysis of the welfare discourses of two populist parties: the Sweden Democrats and the True Finns.
\end{abstract}

Key words: Welfare state; Populist parties; Framing; Nationalism; Nation state 


\section{Introduction}

The rise of new rightist populist parties in Europe joining the parliament and sometimes even government in countries such as Denmark (Dansk Folkeparti), Sweden (Sverigedemokraterna), Finland (Perussuomalaiset), Belgium (Vlaams Belang), Austria (Freiheitliche Partei Österreichs) and Netherlands (Partij Voor de Vrijheid) has created a new dynamic in understanding citizenship in terms of re-defining the boundaries between citizens and noncitizens. This right wing movement can also be seen as challenging the European welfare state tradition by re-defining it as the welfare nation state.

Béland and Lecours have researched the linkages between nationalism and social policy in Canada, the United Kingdom and Belgium (2005; 2008), while Kpessa, Béland and Lecours studied Sub-Saharan Africa (2011). Most of the research on nationalism and social policy has been focused on developed, multinational states (Banting 2005; McEwen 2006; Boychuk 2008; Béland and Lecours 2008). Alesina and Glaeser in turn have argued that 'racial heterogeneity' in the United States explains why it has such a weak redistributive welfare state. People are more likely to look favorably on their own group and for this reason the rather limited redistribution of resources in the Unites States has been linked to views on minorities (2004). Taylor-Gooby has contested this by arguing that the nature of welfare programmes has been more correlated with the strength of left-wing parties than ethnic heterogeneity (2005). Gerdes goes even further and suggests that in Danish municipalities there has been no link between the number of immigrants and public spending (2011). Despite this, Nordic populist parties are voicing their support for a vision where access to welfare is based on ethnic belonging and national borders. The Danish 
People's Party (Dansk Folkeparti) and the Norwegian Progress Party (Framstegspartiet) both support welfare discourses that aim to protect the welfare state from the drain of immigration (Rydgren 2007: 486; Kestilä and Söderlund 2007). We have decided to focus on Finland and Sweden because they demonstrate the most variance within the Nordic cluster across two critical dimensions. First, the Finnish far right is the most actively Eurosceptic of the Nordic far-right movements, whilst in Sweden the far right has been comparatively the least vocal on Eurosceptic issues. Second, Finland's welfare state is the least developed of social democratic welfare states, whilst Sweden is often regarded as the most developed, indeed the ideal type of the social democratic welfare state (Esping-Andersen 1990).

In both Finland and Sweden we can identify a populist right wing discourse that brings together welfare and the nation state. This article argues that the welfare nation state plays an increasingly important role in populist parties as these parties thrive on the threat of immigration and the perceived loss of national sovereignty. We argue that this style of populism does not question a redistributive welfare state; rather it reframes welfare state as being linked to a sovereign and exclusive political community with distinct national boundaries.

Whilst the paper argues that there is a shared populist discourse around the welfare nation state in Finland and Sweden, it also points to important national differences in the way this discourse frames the welfare nation state. The article aims to demonstrate these similarities and differences through a discourse analysis of the two dominant populist parties in Sweden and Finland - the Sweden Democrats and the True Finns - and their efforts at reframing the welfare state in terms of the nation state. While both parties define the welfare state through a narrow, nationalist lens, they focus on different aspects of the nation state: the True Finns focus their rhetoric on the perceived threats to Finland's sovereignty, the European Union in particular while 
the Sweden Democrats focus on the perceived threats that are related to immigration and the ethnic makeup of the population.

This is not wholly surprising: only Finland is part of the Eurozone where the recent financial crisis has fueled an emphatically Eurosceptic public discourse, while over 15 per cent of Swedish population is foreign born, compared with less than 4 per cent in Finland (Tilastokeskus 2014; Svenska Statistika Centralbyrån 2014). Even if each case represents a somewhat different emphasis on welfare and the nation state we argue that together they represent a new welfare nation state populism that cherishes homogeneity while pursuing an active and redistributive welfare strategy that reinforces national sovereignty.

\section{Background}

A key focus of the academic research around political rhetoric far-right parties has been centered on anti-immigration and many contemporary far-right parties actively express their discontent about immigration and ethnic diversity (Ivarsflaten 2008; Rydgren 2008; Van der Brug 2003). Far-right parties have often been understood as 'anti-immigration parties' (Rink et al. 2009; Van der Brug et al. 2000, 2005) and 'movements of exclusion' (Rydgren 2005). Recent research has shown that far-right parties are not just driven by xenophobia and scepticism about immigration but possess a critical attitude towards mainstream politics in general (Rydgren 2007) and have begun to develop mainstream political agendas on issues such as the welfare state (Banting 2010: 798; Rydgren 2004: 486) and the European Union (Kopecký and Mudde, 2002; Szerbiack and Taggart 2008; Raunio 2008; Aylott 2008).

Another set of academic interests has centred on the redistributive policies of the far right. The new rightist parties 'do not necessarily adopt typical rightist stances when it comes to 
issues of economic redistribution and the state' and these 'parties are not by definition opposed to high levels of economic redistribution from the rich to the poor, economic interference by the state, and an extensive welfare state' (Koster, Achterberg and Van der Waal 2013: 4). Koster, Achterberg and Van der Waal claim that new rightist parties' social agenda is to emphasise the interests of the native 'common man' (2013: 4). Despite its gendered tone, we will use the phrase 'common man' throughout the article as this is used in the literature to describe the target audience of right-wing populism.

Often the far-right rhetoric amalgamates the two aforementioned arguments. New rightist parties not only argue against welfare for foreigners but also criticise the way welfare is arranged and delivered in a manner that neglects the interests of the 'common man'. For example, the perception that the needs of asylum seekers, refugees and migrants are prioritized over those of 'natives' is common across the globe (Spinney and Nethery 2013). These parties claim that 'the welfare state is not adequately aimed at helping poor common people who are "really" in need and hence deserving of assistance' and that the 'welfare state, instead, provides well-paid and comfortable jobs for self-interested civil servants who cater to a class of "welfare scroungers" that freeload on the hard work of the "common man"” (Koster, Achterberg and Van der Waal 2013: 6). This gives momentum for an exclusive and exclusionist welfare state that favours ethnic nationals. Such ideas have been branded as welfare chauvinism, implying a strong support for economic redistribution with resistance toward distributing welfare services to immigrants (Van der Waal et al. 2010). Andersen and Bjorklund summarise welfare chauvinism with the description that 'welfare services should be restricted to our own' (1990: 212). These parties suggest they represent a more genuine form of economic egalitarianism, protecting the interests 
of the 'common man' (Betz 1994; Meny and Surel 2000) that challenges the mainstream rhetoric.

This method of presenting the populist politics, we argue in this paper, represents a reframing of the populist political rhetoric through the concept of a welfare nation state among Scandinavian populist parties. But what does this mean? In what sense does the addition of the word 'nation' invite us to rethink the character of the welfare state? The nation state has been understood since the peace treaty at Westphalia 1648 as the dominant political community and could be understood as the dominant political entity and primary political community but it could also be understood as an entity of solidarity among people who may never meet face-to-face. It created what Anderson has defined as an imagined community (1983) where community is not based around face-to-face interactions but on a more abstract idea, creating a bond of solidarity among people who do not have to meet up. 'National identity suggests some kind of perceived or felt homogeneity - whatever people consider as uniting (e.g. a shared language, value system, institutional framework or just the idea of 'us' against 'them')' (Hjerm and Schnabel 2012: 347). The nation state is therefore the most important arena for solidarity among citizens. '[T]he nation state became one of the most important organizational entities for social solidarity, because it provided the fundamentals of a political identity and social morals, which underpin redistributive social security systems' (Mau and Burkhardt 2009: 214). Wagner and Zimmermann call this process the 'nationalization of solidaristic practices' (2003: 254).

In the context of present-day nation states welfare is a key arena for the performance of such solidaristic practices. Kpessa, Béland, Lecours have highlighted how social programmes such as health care, education and income support play a vital role in strengthening the national community defined by the state (2011). They argue that welfare programmes imply a mechanism 
of 'inclusion and exclusion that allow them to build the "in-group" of national community' and that welfare creates bonds and solidarity (2011: 2118). Blyth also suggests that the social democratic welfare state plays a major role in the development of national identity (2002: 123). We argue in this article that populist parties in Finland and Sweden move away from both a universal social democratic and a neo-liberal economic framing of the welfare state and hereby introduce a third framing of the welfare state: the welfare nation state. This in itself is not a new phenomenon since social policy and welfare have often been directly linked to nationalism. What is new is the adoption of these arguments by the far right in Finland and Sweden.

\section{Conceptual framework: The framing of Nordic far-right political discourse}

This paper deals with social policy from a critical interpretative policy perspective. Interpretative policy analysis diverges from mainstream positivist policy analysis by focusing on how policy actors interact and looking at the "the social meaning of policies and the practices in which this meaning is embedded' (Durnova and Zittoun 2011: 103). Moreover, such a perspective seeks to 'develop a deeper, interpretative understanding of policy practices and policy process in general, having extended their scope over time to include perspectives on discourse, narration, governmentality and practice' (2011: 103). This article takes a similar approach to understanding how populist parties frame Nordic states and how this framing is conveyed through a heady mix of nationalism and welfare populism.

The focus lies in the framing of policies in different discourses, an approach often used in

policy research (Compare Béland 2009; Béland and Cox 2011; Blyth 2002; Cox 2001; Hall 1993; Hansen and King 2001; Padamsee 2009). 
This article suggests that populist parties are reframing the Nordic universal and egalitarian welfare state according to a nationalist and ethnic focus; hence the prioritization of access to welfare (access to social citizenship) and the self-determination of the state (national sovereignty) within the discourse. By framing we are referring to something that 'transcends the boundaries of agenda setting' which is often linked to 'stable ideological repertoires' (Béland 2005: 2). One could say that the framing process is a 'strategic and deliberate activity aimed at generating public support for specific policy ideas’ (Béland 2005: 11).

Political actors use framing to convince the population or audience to support a particular policy alternative (Béland 2005). The need for policymakers to frame issues using culturally accepted repertoires shows that public opinion is important (Burstein 1998). Béland argues further that 'frames are dialogical in nature: they anticipate what potential opponents could say to undermine the support for specific policy alternatives' (2005: 11). Béland points out that it is important to 'frame a policy programme in a politically—and culturally - acceptable and desirable manner (which) is a key factor that can help explain why some policy alternatives triumph over others' (2005: 12). The most dominant framings of the Finnish and the Swedish welfare state have been social democratic and neo-liberal which have neglected the recent rise of nationalist alternative reframing of social policy by the far right.

\section{The rationale for the comparison}

We have chosen Finland and Sweden since both of these countries have had recent populist success in the national parliament in the form of the True Finns and the Sweden Democrats. What makes them interesting is the different electoral strategies that led to this success. The True Finns focused primarily on Euroscepticism where the Sweden Democrats focused on 
immigration and multi-culturalism. Yet, despite these differences, we argue that these two parties share a common reframing of social policy in general and the welfare state in particular that is ethnic and nationalist in character, centered around an ethnic and national welfare state.

Moreover, in comparing Finland and Sweden we are comparing the two most different welfare states within the Nordic cluster. While Sweden has been regarded as the ideal social democratic welfare state, with long history of universal welfare services, it was only in the 1980s that Finland's approach to welfare could be characterized as adhering to the social democratic model (Esping-Andersen 1990; Anttonen and Sipilä 2000). The severe financial crisis that hit Finland in the early 1990s meant that statutory provision in areas such as health, pensions and childcare were noticeably curtailed, meaning that the Finnish version of the social democratic welfare state has again become more limited in its coverage (Anttonen and Sipilä 2000: 92). Therefore, in the Nordic context the Swedish and Finnish approaches to the welfare state are the furthest apart and it is these differences that make Finland and Sweden a particularly useful country comparison, as we are able to identify similar welfare nation state discourses among both Finnish and Swedish far-right political parties.

Since our aim is to demonstrate the nationalist reframing of the welfare state by the farright, the article focuses on key documentation published by the True Finns and Sweden Democrats. The main core of our analysis is based on documents published between 2009 and 2012, with emphasis on election documentation such as manifestos. These public documents highlight the growth of nationalist reframing of welfare policies as well as the mainstreaming of far right party rhetoric that has taken place during this period of time.

The analysis of the Sweden Democrats discourse has focused mainly on the following four core documents: 99 förslag för ett bättre Sverige: Sverigedemokraternas kontrakt med 
väljarna 2010 - 2014 (99 suggestions for a better Sweden: Sweden Democrats contracts with the voters 2010 - 2014) published 2010; Sverige Demokraternas Principprogram (Sweden Democrats Principle Manifesto) published in 2011; Arbetsmarknadspolitiskt Inriktningsprogram (Manifesto for Active Labour Market Policy) published in 2011; and Stora besparingar till följd av minskad invandring (Large savings due to decreased immigration) published in 2012.

The analysis of True Finn discourse has been based on the analysis of the following four documents: Perussuomalaisten EU-vaaliohjelma (True Finns' European Election Programme) published in 2009; Perussuomalaisten eduskuntavaaliohjelma (True Finn's Parliamentary Election Programme) published in 2011; The True Finns' Election Programme (an English version of the party manifesto) published in 2011; and Perussuomalaisten Yleisohjelma (The True Finns' General Manifesto) published in 1995. We have had following rationale in choosing these public documents for our main analysis. First, these are public documents used in election campaigns that give an insight to the opinions and attitudes held by the political party in question. Second, these documents therefore tell us of what the priority issues are for the given party with regards to welfare reform. Third, these documents are aimed to persuade voters and are therefore carefully crafted to highlight those issues that communicate the clearest message about the identity of the party.

An additional focus of the research has been on recently published interviews and opinion pieces from leading party members that further clarify the party positions on welfare and nationalism. The criteria for selecting such documents for analysis had to do with their relevance in demonstrating the welfare state attitudes and policies of the far-right parties.

These sources are used as evidence to demonstrate the way the True Finns and Sweden Democrats communicate and frame their discourse around a series of antagonistic positions. As 
we unpack the nationalist framing of the welfare state, we focus on two such positions emerging from these documents. First of all, we demonstrate how the existing welfare state policy is problematized through a nativist perspective, and second, how the solution the welfare state problem can be found through a nationalist reframing of the welfare state.

As both Sweden Democrats and the True Finns rely on a populist framework they are framing their politics in contrast to the established elitist politics that they claim dominate the national discourse. A populist discourse depends on a dichotomy between the neglected interests of the 'common man' which have been sacrificed for the interests of the elite groups in society. Both Sweden Democrats and True Finns frame some of the contemporary issues into a narrative that describes how dominant national elitist have given into external interests (such as economic globalization, immigration and Europeanization) to further their own position in society, weakening the nation state and the homogeneity of the national society. Therefore the solution is actively to strengthen the nation state. This solution requires an active reframing of areas such as the welfare state in national terms; hence the national welfare state regime. This narrative also suggests that populist parties are the sole representatives of the 'common man' and national interest against the elitist and external interests. Table 1 below presents the framing of interests by these two populist parties, depicting the elite being at odds with the rest of society. 


\begin{tabular}{|l|l|l|}
\hline External interest & $\begin{array}{l}\text { Common man interest } \\
\text { Conflict - economic globalization, } \\
\text { immigration and Europeanization are } \\
\text { threats that undermine the nation state }\end{array}$ & $\begin{array}{l}\text { Congruent - elites have used } \\
\text { external interests (globalization, } \\
\text { immigration, EU) to further their } \\
\text { own interests and power. }\end{array}$ \\
\hline National interest & $\begin{array}{l}\text { Congruent - cultural homogeneity and } \\
\text { national sovereignty is in the interest of } \\
\text { the common man which protects their } \\
\text { culture, autonomy and economy. }\end{array}$ & $\begin{array}{l}\text { Conflict - elites have neglected } \\
\text { the interests of the nation through } \\
\text { EU polices, giving in to } \\
\text { globalization and/or opening up } \\
\text { the borders for immigrants. }\end{array}$ \\
\hline
\end{tabular}

Table 1

\section{True Finns}

The True Finns is the most recent reincarnation of a populist party representing the radical right in Finland. It has been modelled on its predecessor, the Finnish Rural Party (Suomen Maaseudun Puolue) that framed its political agenda around the interests of the rural smallholders and other groups whose interests were not served by actions of the political elite, such as the urban working class. Although it lacks the xenophobic extremism that characterises the Danish People's Party and the Sweden Democrats, True Finns stand in support of a mix of traditional conservative and nativist values that locates it firmly in among the populist radical right parties of Europe (Arter 2010). The overall policy rhetoric of the True Finns aims to garner support for a more nationalistic understanding of the Finnish welfare state. As Arter points out, the pivotal 
concept in the True Finn ideology is 'the notion of (true) Finnishness' (2010: 502), an idea that informs much of the True Finn perception of Finland's future. This section demonstrates how the True Finns, guided by this notion of Finnishness, generate an alternative ideological frame that challenges the current reading of social rights and social citizenship in the Finnish context.

First of all, the True Finn party supports a nativist position where a policy of ethnic homogeneity and protection of Finnish culture and values from multiculturalism form the preferred policy. Second, the True Finns adhere to traditional conservative values that emphasize law and order, tougher punishments for public drug and alcohol offences and traditional family values as key sources of social solidarity and cohesion. Third, the True Finn policies see their role as defending the Finnish welfare state model from welfare retrenchment enacted by successive Finnish governments. Finally, the Eurosceptic discourse within the party forms an important part of the overall framing of the threat the True Finns believe the Finnish state is facing. Together, these four aspects of the True Finn political discourse put forward an alternative, nationalistic framing of the problems and solutions that surround the Finnish welfare state, the key aspects of which are summarized in table 2 :

\begin{tabular}{|l|l|l|}
\hline External interest & The True Finns speak of the & The True Finns argue that the \\
protection of Finnish cultural & European Union is a project dreamed \\
values and the national community & up by the political elite that fails to \\
from the artificial societies created & benefit the majority of Finns. \\
by immigration as well as from the & Moreover, it is also a project that \\
European Union that is diluting & been beneficial for the elite which \\
\hline
\end{tabular}




\begin{tabular}{|l|l|l|}
\hline National interest & According to the True Finns, & Multiculturalism favored by the \\
protection of health care, care for & political elite is leading to \\
the elderly and family care must be & 'ghettoization' of communities in the \\
defended. Finnish culture is the & larger suburban centres, and leads to \\
'gift' of Finland to the world that & an overly lenient attitude towards \\
must also be protected.
\end{tabular}

Table 2

The problem: political elite ignores public interest on European issues and immigration policy

The gradual growth of the Eurosceptic discourse has been a particularly salient feature of the True Finns' welfare state critique in recent years. The early policy documents, which make only a brief mention of the European Union, (Perussuomalaiset, 1995), contrast starkly with the 2011 election manifesto where critique of the European Union runs to several paragraphs (Perussuomalaiset 2011a). Whilst economic reasons do also play a part, the key objection is framed in terms of protecting Finland's national sovereignty. The combined effect of the EU, the True Finns argue, is to water down Finland's ability to determine its own policies, which in turn threatens both the political and cultural sovereignty of Finland (Perussuomalaiset 2011a, 2011b). The EU is not democratic, and does not 'support rule by the people', and because of this the voice of Finland is not going to have its rightful say in EU policy or be able to protect its national sovereignty. Moreover, the True Finns criticize policies that belittle the shared Finnish culture, such as the free movement of people, that leave citizens less able to feel part of a single 'national community' (Perussuomalaiset 2009). Key objection to the EU is therefore framed in socio- 
cultural terms as presenting an external threat to Finnish culture and sovereignty. For the True Finns, the Eurosceptic position has been a very visible method of problematizing the current political arrangements through a nationalist lens.

The critique of the actions of the political elite is not limited to EU policy, however. The party rhetoric attacks the 'elitism' of the political class on multiple fronts, suggesting that the public sector and the system for providing public services is being gradually eroded by the ongoing reforms. True Finns are firmly in support of the traditional strong Nordic welfare state model where health, elderly and family care must prioritize the role of the state (Perussuomalaiset 2011a).

Another policy area where the problems with the current system are often demonstrated is that of immigration. The official party policy carefully distinguishes between 'neutral' and 'bad' immigration, accepting the positive contribution of highly skilled immigrants while highlighting others as a potential drain on the Finnish economy. Immigration is not a problem on the whole, but at the same time Finland should remain vigilant against non-work-based immigration. In particular, the party raises concerns over multiculturalism and the trend of 'ghettoization' it sees taking place elsewhere in Europe as a consequence of this policy. Immigrants move to the suburbs of the larger cities and create 'artificial societies' that have little contact with 'normal society' and fail to learn the Finnish language (Perussuomalaiset 2011a). At the far end of the scale we find commentators such as Jussi Halla-Aho, a member of parliament for the True Finns, who is highly critical of the impact of immigration and its liberal defenders. In his blog he draws a correlation between immigration and an increase in the number of rapes. Halla-Aho comments: 
Since more and more women are going to be raped in any case, I hope and pray that the victims randomly selected by these predators would be the right women. The leftistsgreen do-gooders and their constituents. Rather them than someone else. They are not going to react to anything other than the fact that multiculturalism comes home to roost. (Halla-Aho 2006, cf. Aden 2009)

It is in these ways that the ethno-nationalist and socio-economic arguments blend in the True Finn policy as it carefully frames the discussions of immigration.

The solution: welfare nativism to protect Finnish culture and families

Ethno-nationalism is the key idea that holds together the national welfare state rhetoric for the True Finns. A document outlining the core values of the True Finns states this in no uncertain terms: 'Finnishness is a strength' (Suomalaisuus on voima) (Perussuomalaiset 2011a). Indeed, as the name of the party intimates, the values underpinning most policies can be found in Finnish history and culture. For this reason, multiculturalism cannot replace Finnish national identity, which the True Finns regard Finland's 'gift' (lahja) to the world. The True Finn values aim to highlight the uniqueness of Finland and being Finnish, and strengthen the common national identity that is the 'basis of the social contract'. It is in this context that the role of the Finnish language is highlighted as an important aspect of cultural heritage in need of protection. The protection of Finnishness and Finnish culture is an important rationale informing the True Finns' approach to social policy more generally. For example, the motto "When in Rome, do as the Roman's do' can be found in the 2011 manifesto, alluding to the importance of cultural and legal 
norms that ought to inform immigration and integration policy. It further opines that '[n]ormal immigrants value the same things as normal Finns: reasonable taxes, good education, social harmony and security. Bad immigration chips away at the base of these attractions' (2011a: 40).

In addition, the True Finn discourse identifies with traditional conservative values, in particular with traditional, ethno-national family values. For example, for the True Finns the solution to Finland's ageing population can be found in a stronger family policy that supports young families rather than following the 'odd' (erikoista) current policy that imports immigrant workers (2011a: 23). The True Finns are in support of a 'traditional' family unit where both parents - mother and father - are present. More broadly, the support for traditional family values can also be identified in the party's support for religious teaching at schools, which should not be watered down (2011b). The current welfare system, the True Finns argue, fails to offer adequate support to families, and to young families in particular who are at their 'best child-bearing age' (parhaassa hedelmällisyysiässä) (2011a: 23).

True Finns support the idea of a universal welfare state. Access and the ability of people to make claims on the welfare state are seen as critical pillars of democracy. However, for the True Finns the current state of welfare represents the demands of elitist democracy that is more concerned with the opinions of experts. This is one aspect of re-framing the current system as broken: it is failing the working class. The second aspect of this re-framing is the way in which the proposed remedy is framed in terms of national welfare state that protects the interests of the everyday Finn by protecting the political and cultural sovereignty of Finland. 


\section{Sweden Democrats}

The Sweden Democrats is a relatively young party. It was founded in 1988 as a successor to the Sweden party which itself was a merger between two right wing parties in 1986. The Swedish progress party (Framstegspartiet) and Keep Sweden Swedish (Bevara Sverige Svenskt) joined up forces (Compare Rydgren 2011). The party spent much of the late 1990s cutting the links to extreme groups and becoming a more respectable mainstream party. When Jimmy Åkesson took over the party in 2005 the party aimed to emulate the successes of the Danish People's Party and enter the national parliament. In the election in 2006 the party received 2.9 percent of the votes in the national election and 280 mandates in municipal councils. At that point the party failed to reach the election threshold of 4 percent. In the election 2010 the party achieved considerable success with 5.7 percent of the national vote, which gave them 20 seats in the Swedish parliament and 612 mandates in municipal councils (compare Rydgren 2011).

The party focuses on the national identity of Sweden and the composition of the population. Rydgren states that this rests on a relationship between the Swedish people and its culture. Sweden Democrats ideology is based on linking people and culture to the concept of the nation state. The party takes for granted that each nation embodies one ethnically determined culture. Sweden Democrats have a nostalgic relationship to the past where Sweden was a more homogenous society (Rydgren 2003). The party sees itself as above the divide between left and right - it focus just as much on traditional right wing issues such as law and order, nationalism, protecting heritage as it focus on safeguarding the welfare state, looking after the old and protecting the environment.

The party wants to safeguard the Swedish welfare state and argues that tax reductions should never happen at the detriment of the Swedish Welfare state. In many ways the Sweden 
Democrats are a populist party with right wing elements (nationalism, nation state, xenophobia, security) but their party programme also contains certain Nordic values such as strong support for the Swedish welfare state and opposition to the death penalty. The four aspects of the Sweden Democrats' political discourse are summarized in table 3:

\begin{tabular}{|l|l|l|}
\hline External interest & Elite interest \\
\hline $\begin{array}{l}\text { Sweden democrats argue that it is } \\
\text { in the national interest to limit the } \\
\text { flow of immigrants to Sweden } \\
\text { since this will protect the Swedish } \\
\text { culture, welfare state, labor market } \\
\text { and reduce crime. The external } \\
\text { interests of other cultures should } \\
\text { implementing a multi-cultural society } \\
\text { the elite have given in to interests of } \\
\text { other cultures and in particular Islam. } \\
\text { This has lead to a neglect of } \\
\text { commoners interest in promoting a } \\
\text { that Swedish will be supported } \\
\text { more through better welfare, better } \\
\text { access to employment and safety. }\end{array}$ & $\begin{array}{l}\text { Swedish identity, promote } \\
\text { employment for Swedes, curtail } \\
\text { immigrants abuse of welfare system, } \\
\text { protect Swedes from crime committed } \\
\text { by immigrants and allow employers } \\
\text { to introduce foreign workers to } \\
\text { compete with Swedish works. }\end{array}$ \\
\hline National interest & $\begin{array}{l}\text { The Swedish Democratic Party } \\
\text { argues that it is in the interest of } \\
\text { the common man to uphold the } \\
\text { nation state as territory governed } \\
\text { by dominant nation and culture. } \\
\text { Political and cultural influence } \\
\text { from abroad should be limited to } \\
\text { different degrees. On the other side } \\
\text { Sweden Democrats are for global } \\
\text { free trade which makes their stand } \\
\text { ambiguous. }\end{array}$ & $\begin{array}{l}\text { The } \\
\text { political elite is defined as being run } \\
\text { by ideology and therefore ignores } \\
\text { the nation state. This elite has become } \\
\text { a political class that is supported by } \\
\text { mainstream media that ignores that } \\
\text { the nation state is undermined by } \\
\text { immigration and multi-culturalism. } \\
\text { The elite are therefore accused for } \\
\text { being against the interest of the nation } \\
\text { state. }\end{array}$ \\
\hline
\end{tabular}

Table 3

The problem: elitist multiculturalism is a threat to the Swedish society

The Sweden Democrats argue that the contemporary problem of Sweden is the ruling elite that abandons the interest of the common man and national interests for the sake of their own and 
external interests. They claim to have been victims of a dominant elitist discourse in Sweden that is dominated by the political and media elites. The party argues that this order favours approved, internationally oriented politicians and their elite positions in society (Sverigedemokraterna 2002).

The party perceive the dominant political class as a threat because of its support for mass immigration. The party argues that this political class has implemented an irresponsible immigration policy designed to create a 'multicultural society' which has led to new ethnic minorities living in Sweden who do not define themselves as Swedish or as being part of Swedish history or culture (Sverigedemokraterna 2002). The populist aspect of Sweden Democrats is to represent the voice of the common man in Sweden. The greatest threat of multiculturalism is the acceptance of Islam and here Sweden Democrats go rather far in describing Islam as a national threat. A debate article in the Swedish daily Aftonbladet by the party leader Jimmie Åkesson (2009) frames 'Muslims' as the greatest 'foreign' (utländska) threat, leading to Sweden and Europe becoming Islamized and under threat from Sharia law.

The Sweden Democrats also suggest that immigrants induce large economic costs onto Swedish society and the Swedish people. The framing of immigrants as a cost and a burden is very much the dominant perception where the party argues that immigrants tend to be unemployed and heavily reliant on the welfare state. Moreover, the negative impact of immigration on the labour market is often highlighted.

Sweden Democrats argue that the 'free work immigration that was introduced in 2008' has placed a great strain on the labour market. It has meant that Swedes have been pushed out of jobs and wages have been reduced. 'What happened in practice was that one transferred all responsibility to employers when it came to work immigration of people from outside the 
EU/EEA' (Sweden Democrats 2011b). The party argues that this has led to low wages for people in the service industry in particular. The party also highlights that programmes that promote positive discrimination towards immigrants on the labour markets is a hurdle for Swedish workers. It is therefore assumed that immigrants lead to higher costs as well as lower salaries for Swedish workers and a decline in the labour market. There is an implicit criticism of employers and their self-interest in keeping wages low.

A large part of the rhetoric has focused on immigrants not just as being religious fundamentalists and a cost to society but also prone to crime. The safety of the average citizen has been neglected in order to protect the immigrants. Immigrants are often portrayed by the Sweden Democrats to have particularly significant role in violent and sexual crime, as the following advertisement from 1996 shows: 'Drugs...Violence...AIDS...Crime... Immigration... Do you like living in the multicultural society?' (cited in Rydgren 2011:25).

The solution: prioritize welfare support for Swedes

The Sweden Democrats resists a multi-cultural society where their main aim is to protect Swedish national identity. The party argues that immigration must be kept so low that it does not threaten the national identity, the welfare state or the security (trygghet) of the Swedish people. The party states that one needs to limit the amount of asylum seekers to a minimum according to the UNs refugees' convention. They should only stay as long as they are threatened in their home country. The party also states that it is better to help the asylum seekers in their home country instead of allowing them into Sweden (Sverigedemokraterna 2011a). 
Sweden should be a nation state and its welfare state ought to be first and foremost for the Swedes. 'In our Sweden we help people in distress but the Swedish welfare and the wellbeing of the country will be the first priority. In our Sweden there will be responsible immigration politics.' The party therefore argues for a reduction in the number of asylum-seekers and relatives of immigrants entering the country to the levels found in neighbouring Denmark and Finland. The party also demands assimilation of immigrants rather than integration (Sverigedemokraterna 2011a). The Sweden Democrats also argue that jobs in the Swedish labour market should go first and foremost to Swedish nationals. Temporary visas should be given to immigrants to fill gaps in the labour market but the party insists that such workers should return home afterwards. The labour market should be influenced by the nation and the nation state.

The Sweden Democrats have therefore included cutting spending on asylum and immigrants as an important part of their budget proposals. They argued in 2012, with widely disputed calculations, that the net cost of new immigration is 119 billion Swedish Kronor while immigrants use social services 1.5 times more than ethnic Swedes. Additionally, here we encounter the argument that a reduction in the number of immigrants will lead to an overall improvement of the nation state and its citizens (Sverigedemokraterna 2012). 'All political activity is about creating priorities and it is up to ourselves to decide where we want our common resources to go. Sweden Democrats have shown that one can through immigration politics free up resources that could be used to lower tax pressures and raise welfare' (Sverigedemokraterna 2012).

Key policies for the Sweden Democrats include not only restrictions on immigration but also initiatives to support people to leave Sweden, arguing that 'there should be an active and generous support to be given to immigrants who wish to return to their home countries' 
(Sverigedemokraterna 2010). The restrictive measures would also mean that Swedish citizenship should be harder to attain where citizenship would require a 10 -year residency. The Sweden Democrats believe in a multicultural world based on the nation state where territorial boundaries highlight the geographic area of a specific nation. They argue that a cultural diversity is important but that cultures should be kept apart in order for them to thrive. In the words of the party secretary, the Sweden Democrats argue further that it is important to strengthen the Swedish nation state. 'In our Sweden, Sweden is allowed to be just Sweden, and its inhabitants are allowed to be just Swedish. In our Sweden the Swedish people have the power, through elections, to shape their own common future. In our Sweden the Swedish parliament is the highest decision-making body' (Sverigedemokraterna 2010).

\section{Analysis}

We argue that populist parties are reframing social citizenship within a welfare nation state where the lack of sovereignty and expansive access to social rights are framed as a threat. Both the True Finns and the Sweden Democrats propose a welfare nation state as a guiding discourse for their policies where the sovereignty and exclusivity of Swedes and Finns in a more globalised and inter-connected world is protected.

This is not to say there are no differences. The most salient distinction relates to the role played by Eurosceptic attitudes and the nature of the anti-immigration rhetoric. In the Finnish case, the European Union plays a very significant role in the process of developing a distinct party identity for the True Finns. In the Swedish case, the critique of multiculturalism and antiimmigrant policies is articulated much more strongly. However, these differences should be seen more as 'background noise' rather than substantive ideological differences because the two 
parties are aiming to claim different types of political space among the mainstream parties. In the case of Sweden, Euroscepticism has been firmly rooted in mainstream politics for a long time (Aylott 2008) while in Finland only a few years ago the analysis of Euroscepticism focused on explaining the absence of Euroscepticism (Raunio 2008). It should therefore not come as a surprise that the populist right wing parties in the two countries are likely to adopt different political strategies. The second difference relates to the prevalence and frequency of the antiimmigrant narrative in the party rhetoric. Whilst present in both cases, in the Swedish case it takes a more salient role in the overall rhetoric. We argue that this is again a symptom of different circumstances rather than a substantive difference in the underlining ideology.

Through the case studies, we have essayed to present a populist political strategy that falls along two sets of axes. On the one hand this strategy is strongly in support of the interests of the 'common man', which are seen to align with the broader national interests of autonomy, cultural homogeneity and national sovereignty. Moreover, this 'common man' position is used to problematize the external interests that prioritise globalization, Europeanization and immigration. On the other hand, the populist political rhetoric presents the political and economic elite as neglecting the national interests of the working classes. The elites' preference for globalization and immigration threatens the interests of the average citizen whose welfare, culture and autonomy are challenged by these external threats. Thus, as shown in table 4 , it is the juxtaposition of the national and the external domains on top of a narrative that compares the 'common man' against the elites that generates the rhetorical momentum of the Finnish and Swedish populist movements. 


\begin{tabular}{|l|l|}
\hline Common-man nationalism & Elitist globalization \\
\hline Sovereign nation state & Loss of sovereignty \\
Strengthening of borders & Blurring of borders \\
Strong link between citizens and social rights & Loss of exclusive social rights for citizens \\
Homogenous societies based within national & Multicultural societies based around \\
borders & European Union \\
\hline
\end{tabular}

Table 4

Still one needs to see the rise of a new rightist populist discourse around the welfare nation state as being in direct opposition with the overall development of welfare and social policy in Europe. First, social policy has often been framed as being universalist and egalitarian, and in this sense creating a citizenship of its own. Some take this further and argue that social benefits and social policy could create a citizenship in countries that had ethnic diversity (Compare Leibfried and Pierson 2000; Obinger et al. 2005). However, at the same time many scholars describe the Nordic universal and egalitarian system as one that is creating social services that are de-coupled from nationality or ethnic origin. Universal welfare services should not discriminate any citizens (Rothstein and Stolle 2003:196). There is even the argument that welfare states create a citizenship that is independent of ethnic, religious and racial lines (compare Rothstein and Uslaner 2005).

Sweden and Finland have followed the same trajectory with most European countries where social policy has focused less and less on national citizenship in the granting of social 
rights. Residency has often replaced legal citizenship as the grounds for access to social services. Since the 1950s and 60s there has been a gradual 'denationalization of solidarity practices' where people with permanent residency have access to a wide range of citizenship rights (Mau and Burkhardt 2009: 214). With a continuing integration of the European nation states, the sovereignty of nations has been confronted by a more federal and less nationalistic system of decision making. Therefore, the reaction against access to social policy on the bases of domicile, as it is the case for immigrants, is largely based on the fact that the vision of welfare being based on citizenship is being challenged (Sainsbury 2006). The integration into the EU has led to a loss of sovereignty on social issues, which has played a large role in both cases and in the rhetoric of the True Finns in particular.

The dominant understanding of social policy has become disconnected from the ethnic origin of the nation state. As social citizenship has become more and more de-nationalized, the opposite point of view has been far less conceptualized. Populist parties have begun to reframe not just political rights but also social and economic rights as exclusive rights for cultural and/or ethnic members of that particular nation state. Some call this development the rise of welfare chauvinism where radical right-wing parties become supporters of the welfare state (Betz and Johnson 2004; Evans et al. 2001).This attitude is responsible for much of the resentment of the host society against immigrants insofar as they are perceived to 'take away jobs, housing, and social services' (Faist 1994: 440). The new rightist discourse therefore argues that social policy should be directly linked with an ethnic and sovereign nation state.

We can therefore identify a narrative that pivots around the concepts of welfare and the nation state. In the case of both parties it is possible to identify a strong class-based argument about the importance of the welfare state and the redistributive mechanisms that is aligns with. In 
other words, there is a particular language of social and economic rights attached to the populism of True Finns and Sweden Democrats that aims to protect the rights of the native working classes, who are identified as the group who have lost the most as a consequence of globalization and open borders. This, in sum, is the logic and narrative of the welfare nation state that guides the agenda of the Nordic populist right.

\section{Conclusion}

From a conceptual point of view this paper has argued that it is helpful to consider the discourse of the Finnish and Swedish populist parties from the perspective of welfare nation state. The contemporary welfare state is commonly framed in terms of the social and economic rights that it confers to its citizens. Populist parties are reframing the Swedish welfare from a universal and egalitarian citizenship discourse through the lens of the nation state. The populist rhetoric reconfers social rights as belonging to the membership of a particular community, narrowing and strengthening the boundaries of belonging, and establishing more effective controls around this. However, whilst the rules of exclusion and inclusion are strengthened, the social and economic rights of those within the community are enhanced. In other words, the populist ideology is also strongly attached to progressive notions of equity and improved mechanisms of redistribution.

This approach sits uneasily among the multicultural, interconnected and increasingly global set of institutions and networks that the modern nation-state finds itself in. For this reason the language of limited national community of citizens is accompanied by strengthened notions of nation state sovereignty. It is in this way that the present-day populist discourse weaves together social and economic rights, nationalism and sovereignty. The evidence presented in this 
article suggests that such framing of the rhetoric of the welfare nation state is something that both the Finnish and Swedish populist right wing parties share.

\section{Bibliography:}

Aden, S. (2009), Ikuisesti pakolaisina? Maahanmuuttikeskustelu Suomen somalialaisten näkökulmasta. In S. Keskinen, A. Rastas and S. Tuori (eds), En ole rasisti, mutta... Maahanmuutosta, monikulttuurisuudesta ja kritiikistä, Tampere: Vastapaino, pp. 25-32.

Alesina A. and Glaeser, E. (2004), Fighting Poverty in the US and Europe: A World of Difference, Oxford: Oxford University Press.

Anderson, B.R.O. (1983), Imagined Communities: Reflections on the Origin and Spread of Nationalism, London: Verso.

Anttonen, A. and Sipilä, J. (2000) Suomalaista Sosiaalipolitiikkaa, Jyväskylä: Vastapaino.

Arter, D. (2010), The breakthrough of another West European populist radical right party? The case of the True Finns, Government and Opposition, 45, 4: 484-504.

Banting, K. (2005), Canada: National-building in a federal welfare state. In H. Obinger, S. Leibfried and F. G. Castles (eds), Federalism and the Welfare State: New World and European Experiences, Cambridge: Cambridge University Press 
Béland, D. (2005), The Politics of Social Policy Language, Social Policy \& Administration, 45, 1: $1-18$.

Béland, D. (2009), Gender, Ideational Analysis, and Social Policy, Social Politics, 16, 4: 558-81.

Béland, D. and Cox, R. H. (2011), Ideas and Politics in Social Science Research, NewYork, NY:

Oxford University Press.

Béland, D and Lecours, D. (2005), The Politics of Territorial Solidarity: Nationalism and Social Policy Reform in Canada, the United Kingdom and Belgium, Comparative Political Studies, 38, 6: 676-703.

Béland, D and Lecours, D. (2008), Nationalism and Social Policy: The Politics of Territorial Solidarity, Oxford: Oxford University Press.

Betz HG, and Johnson C. (2004), Against the current - stemming the tide: the nostalgic ideology of the contemporary radical populist right, Journal of Political Ideology, 9, 3: 311-27.

Bloch, A. (2008), Refugees in the UK Labour Market: The contention between economic integration and policy-led labour market restriction, Journal of Social Policy 37, 1: 21-36.

Blyth, M. (1997), Moving the Political Middle: Redefining the Boundaries of State Action, Political Quarterly, 68, 3: 231-40. 
Blyth, M. (2002), Great Transformations: Economic Ideas and Institutional Change in the Twentieth Century, Cambridge: Cambridge University Press.

Boychuk, G. (2008), National Health Insurance in the United States and Canada: Race, Territory, and the Roots of Difference, Washington, DC: Georgetown University Press.

Brockmann, M. and Fisher, M. (2001), Older Migrants and Social Care in Austria, Journal of European Social Policy, 11, 4: 353-62.

Brubaker, W.R. (1992), Citizenship and Nationhood in France and Germany, Cambridge, Cambridge University Press.

Burgoon, B., Koster, F. and van Egmond, M. (2012), Support for redistribution and the paradox of immigration, Journal of European Social Policy, 22, 3: 288-304.

Cox, R. H. (2001), The Social Construction of an Imperative: Why Welfare Reform Happened in Denmark and the Netherlands but Not in Germany, World Politics, 53, 3: 463-98.

Durnova, A and Zittoun, P. (2010), Introduction: Interpretive policy analysis in a French setting. The Fifth Interpretive Policy Analysis Conference, Grenoble, June 2010, Critical Policy Studies, 5, 2: 103-105.

Esping-Andersen, G. (1990), The Three Worlds of Welfare Capitalism, Cambridge: Polity Press. 
Evans, J., Arzheimer, K., Baldini, G., Bjorklund, T., Carter, E. et al. (2001), Comparative mapping of extreme right electoral dynamics: an overview of EREPS, European Political Science 1, 1: 42-53.

Faist, T. (1994), Immigration, integration, and the ethnicization of politics, European Journal of Political Research, 25, 4: 439-459.

Gerdes, C. (2011), The Impact of Immigration on the Size of Government: Empirical Evidence from Danish Municipalities, Scandinavian Journal of Economics, 113, 1: 74-92.

Hall, P. A. (1993), Policy Paradigms, Social Learning and the State: The Case of Economic Policymaking in Britain, Comparative Politics, 25, 3: 275-96.

Halla-Aho, J. (2006), Monikulttuurisuus ja nainen. http://www.hallaaho.com/scripta/monikulttuurisuus_ja_nainen.html (Accessed 10 April 2013).

Hansen, R. and King, D. (2001), Eugenic Ideas, Political Interests, and Policy Variance: Immigration and Sterilization Policy in Britain and the U.S., World Politics, 53, 2: 237-63.

Hjerm, M. and Schnabel, A. (2012), How much heterogeneity can the welfare state endure? The influence of heterogeneity on attitudes to the welfare state. Nations and Nationalism, 18, 2: 346369. 
Johansson, H. and Hvinden, B. (2007), Nordic activation reforms in a European context: a distinct universalistic model. In B. Hvinden and H. Johansson (eds), Citizenship in Nordic Welfare States: Dynamics of Choice, Duties and Participation in a Changing Europe, London: Routledge, pp. 53-67.

Kestilä, E. and Söderlund, P. (2007), Local determinants of radical right-wing voting: The case of the Norwegian progress party, West European Politics, 30, 3: 549-57.

Kpessa, M., Béland, D. and Lecours, A. (2011), Nationalism, development, and social policy: The politics of nation-building in sub-Saharan Africa, Ethnic and Racial Studies, 34, 12: 21152133.

Larsen, C.A. (2011), Ethnic Heterogeneity and Public Support for Welfare: Is the American Experience Replicated in Britain, Sweden and Denmark? Scandinavian Political Studies, 34, 4: $332-53$.

Leibfried, S. and Pierson, P. (2000), Social policy: Left to courts or markets. In H. Wallace and W. Wallace (eds), Policy-making in the European Union, Oxford, UK: Oxford University Press: pp. 267-89.

Mau, S. and Burkhardt, C. (2009), Migration and welfare state solidarity in Western Europe, Journal of European Social Policy, 19, 3: 213-29.

McEwen, N. (2006), Nationalism and the State: Welfare and Identity in Scotland and 
Quebec, Brussels: Peter Lang.

McVeigh, R. (2007), The 'Final Solution': Reformism Ethnicity Denial and the Politics of Anti-Travellerism in Ireland, Social Policy and Society, 7, 1: 91-102.

Nordensvärd, J. (2010), The Consumer Metaphor versus the Citizen Metaphor in Education Policy. In M. Molesworth, E. Nixon and R. Scullions (eds). The Marketisation of Higher Education: The Student as Consumer, Abingdon: Routledge, pp. 157-169.

Obinger, H., Leibfried, S. and Castles, F. (2005), Old and new politics in federal welfare states. In S. Leibfried, H. Obinger and F. Castles (eds), Federalism and the welfare state. New World and European experiences Cambridge, MA: Cambridge University Press, pp. 307-353.

Padamsee, T. (2009), Culture in Connection: Re-Contextualizing Ideational Processes in the Analysis of Policy Development, Social Politics, 16, 4: 413-45.

Perussuomalaiset (1995), Yleisohjelma. http://www.perussuomalaiset.fi/ohjelmat/. (Accessed 10 April 2013).

Perussuomalaiset (2009), Perussuomalaisten EU-vaaliohjelma 2009.

http://www.perussuomalaiset.fi/ohjelmat/. (Accessed 10 April 2013). 
Perussuomalaiset (2011a), Perussuomalaisten eduskuntavaaliohjelma 2011

http://www.perussuomalaiset.fi/ohjelmat/. (Accessed 10 April 2013).

Perussuomalaiset (2011b), The True Finns' election programme for the parliamentary election 2011 - summary. http://www.perussuomalaiset.fi/ohjelmat/. (Accessed 10 April 2013).

Raunio, T. (2008), The difficult task of opposing Europe: the Finnish party politics of Euroscepticism. In A. Szczerbiak and P. A. Taggart (eds), Opposing Europe? The comparative party politics of Euroscepticism vol. 1, Oxford: Oxford University Press, pp. 168-80.

Rothstein B. (2001), The Universal Welfare State as a Social Dilemma, Rationality and Society, 13, 2: 213-33.

Rothstein, B., and Stolle, D. (2003), Social capital, impartiality and the welfare state: An institutional approach. In M. Hooghe and D. Stolle (eds), Generating social capital, New York: Palgrave MacMillan, pp. 191-210.

Rothstein, B. and Uslaner, E.M. (2005), All for One: Equality, Corruption, and Social Trust. World Politics 58, 1: 41-72.

Rydgren, J. (2003), The Populist Challenge: Political Protest and Ethno-nationalist Mobilization in France. New York: Berghahn Books. 
Rydgren, J. (2005), Radical right-wing populism in Sweden and Denmark, Beer Sheva, The Centre for the Study of European Politics and Society

Rydgren, J. (2007), Explaining the Emergence of Radical Right-Wing Populist Parties: Case of Denmark, West European Politics, 27, 3: 474-502.

Sainsbury, D. (2006), Immigrants' social rights in comparative perspective: welfare regimes, forms in immigration and immigration policy regimes, Journal of European Social Policy, 16, 3 : $229-44$.

Spinney, A. and Nethery, A. (2013), 'Taking our houses': Perceptions of the impact of asylum seekers, refugees and new migrants on housing assistance in Melbourne, Social Policy and Society, 12, 2: 179-89.

Stephens, J. D. (1996), The Scandinavian Welfare States: Achievements, Crisis, and Prospects. In G. Esping-Andersen (ed.), Welfare States in Transition. London: Sage, pp. 32-65.

Svenska Statistiska Centralbyrån (2012), Grundtabeller årsmedeltal 2012, Stockholm: Statistiska centralbyrån. http://www.scb.se/Statistik/AM/AM0401/2013A01G/AKU2013_1574.xls. (Accessed 28 February 2014).

Svenska Statistiska Centralbyrån (2014), Population Statistics. http://www.scb.se/en_/Findingstatistics/Statistics-by-subject-area/Population/Population-composition/Population-statistics/. (Accessed 28 February 2014). 
Sverigedemokraterna (2002), Partiprogram 1999 med justeringar 2002.

www.sverigedemokraterna.se. (Accessed May 2013).

Sverigedemokraterna (2010), 99 förslag för ett bättre Sverige : Sverigedemokraternas kontrakt med väljarna 2010 - 2014. www.sverigedemokraterna.se. (Accessed May 2013).

Sverigedemokraterna (2011a), Sverigedemokraternas principprogram 2011. www.sverigedemokraterna.se (Accessed 5 March 2013).

Sverigedemokraterna (2011b), Arbetsmarknadspolitiskt inriktningsprogram. www.sverigedemokraterna.se. (Accessed 5 March 2013).

Sverigedemoraterna (2012), Stora besparingar till följd av minskad invandring. www.sverigedemokraterna.se. (Accessed on 5 March 2013).

Szczerbiak, A. and Taggart, P. A. (2008), Opposing Europe? The comparative party politics of Euroscepticism Vol. 1, Oxford: Oxford University Press.

Taylor-Gooby, P. (2005), Is the Future American? Can Left Politics Preserve EuropeanWelfare States from Erosion through Growing 'Racial' Diversity? Journal of Social Policy, 34, 4: 66172. 
Tilastokeskus (2014), 'Population'.

http://www.stat.fi/tup/suoluk/suoluk_vaesto_en.html\#foreigners. (Accessed 27 February 2014).

Wagner, A. (2004), Redefining citizenship for the 21st century: from the National Welfare State to the UN Global Compact, International Journal of Social Welfare, 13, 4: 278-86.

Wagner, P. and Zimmermann, B. (2003), 'Nation. Die Konstitution einer politischen Ordnung als Verantwortungsgemeinschaft'. In S. Lessenich (ed.) Wohlfahrtsstaatliche

Grundbegriffe.Historische und aktuelle Diskurse. Frankfurt a.M./New York, NY: Campus, pp. $243-266$.

Åkesson, J. (2009), Muslimerna är vårt största utländska hot, Aftonbladet 19 October. 